\title{
Missing Items in Zakat Distribution: A Case in Kelantan, Malaysia
}

\author{
Ahmad Fahme Mohd Ali, Mohd Faisol Ibrahim, and Muhammad Ridhwan Ab Aziz. \\ Faculty of Economics and Muamalat, Universiti Sains Islam Malaysia
}

\begin{abstract}
This study attempts to analyze missing items in current zakat distribution among the poor and needy zakat recipients in Kelantan. The study is motivated by few shortcomings of current zakat distribution as well as an increasing amount of expenditure annually on the two categories of zakat recipients, and yet the number of poor (fuqara) and needy (masakin) households is increasing. The current amount of zakat monthly distribution seems to raise some issues due to its weaknesses. This paper examines several missing elements in the current zakat distribution in Kelantan, Malaysia. The research was conducted through in-depth interviews with selected zakat recipients from a variety of socio-economic-cultural backgrounds in Kelantan, Malaysia. This study recommends that these items should be included in future zakat distribution in order to improve and strengthen the Muslims economy condition, and then, it would facilitate the poverty alleviation programs by the zakat department.
\end{abstract}

Keywords: Zakat Poverty Line, Had Kifayah, Poor and Needy, Kelantan, Malaysia

\section{INTRODUCTION}

Zakat (Almsgiving) is one of the most important instruments in the Islamic economic system, and it plays a significant role in eliminating inequalities in society. Muslims who possess surplus wealth are obligated to pay zakat, and this fund will be distributed to prescribed eight beneficiaries known as zakat recipient (asnaf) group with the priority given to the poor and needy.

The general principle of zakat distribution has been laid down clearly in the Qur'an as underlined in Surah AlTaubah verse 60 that states: "Alms are for the poor and the needy, and those employed to administer the (funds) for those whose hearts have been (recently) reconciled (to Truth) for those in bondage and debt in the cause of Allah and the wayfarer: (thus is it) ordained by Allah, and Allah is full of knowledge and wisdom".

The purpose of distributing zakat fund is to alleviate poverty, to protect the welfare, to improve economic hardship and to develop the infrastructure of Muslim society through the redistribution the income and wealth from the wealthy to the needy (Yusuf Qardhawi, 2000). In Malaysia, the responsibility of the collection and distribution zakat fund is empowered to zakat institutions in which every 14 state in Malaysia has its zakat institutions. Indeed, the effectiveness of zakat distribution manage by the zakat institutions has become the main concern in Muslim's society as they hope that the fund could 
free the recipients from poverty or improve their quality of living.

In determine the qualified zakat recipients, most zakat institutions in Malaysia use the monetary approach called Zakat Poverty Line (ZPLI) or Had Kifayah $^{1}$ (HK) method. It is almost identical as the Government Poverty Line Income (PLI) because it uses income as the variable to determine whether the individual or household is poor or otherwise (Fahme, 2014; Mohamed Saladin Abdul Rasool e.t al, 2011). PLI is set by the Economic Planning Unit (EPU) of the Prime Minister Department, while $\mathrm{Had}$ Kifayah is determined by the respective state zakat institution. Had Kifayah determines the level of necessity needed by a household to sustain daily needs. It is calculated based on various variables such as the number of members in a family, age group of members, etc. JAWHAR $^{2}$ (2007) has outlined the main components in determining $\mathrm{Had}$ Kifayah (necessity) of a household as shelter, food, clothing, health, education, and transportation based on Maqasid al Sharia (human needs). The setting of Had Kifayah will ease the process of identifying the position of the applicants straightaway, namely whether non-poor, poor, or hard-core poor. Table 1 shows the amount of had kifayah based on the household category in Kelantan.

Table 1 shows the amount of the zakat poverty line based on the necessity of a household in Kelantan. For example, a family with both parents working, a teenager aged 21 in university, a school teenager aged 16 , a child aged 10 and 5 and living in a paid

\footnotetext{
${ }^{1}$ Had al-kifayah is sustainable needs level according to Islamic principles, i.e amount needed by a household to fulfill their basic needs in accordance with the Sharia point of view, hereafter termed as Had Kifayah.

${ }^{2}$ Department of Awqaf, Zakat and Hajj
}

house in the urban area is suggested to need MYR 1,578.50 3 for the household. If the monthly household income is RM 2000 , then this family is not qualified for zakat distribution because the household income is more than the ZPLI of this household (above MYR 1578.50). Nevertheless, if the household income is MYR 1000, then this household is qualified for zakat distribution. Kelantan Zakat Centre (MAIK) will distribute the shortfall (ZPLI gap) of MYR 578.5 to this family to fulfill their basic needs. In addition, if there is any situation such as households with a disabled individual or one with a chronic sickness, the total amount of ZPLI increases.

The Kelantan zakat poverty line (Had Kifayah) is an absolute poverty line based on the gross monthly household income that is required to meet their basic needs. It is estimated based on food and non-food items and the cost of basic needs $(\mathrm{CBN})$ approach (MAIK, 2013). In general, the CBN approach entails stipulating a food consumption bundle anchored to calorie requirements, as an artifice to determining the cost of the minimum food nutritional (calorie) requirements of everyone, and adding a non-food allowance based on the non-food budget shares of poor households, to obtain a total poverty line which represents an acceptable standard of living in society.

\footnotetext{
${ }^{3}$ MYR 549+ MYR 236.5+ MYR 274+ MYR

236.5+ MYR 179.5+ MYR103 = MYR 1,578.5
} 
Table 1. Kelantan Zakat Poverty Line (Had kifayah) Per Month (2014)

\begin{tabular}{|c|c|c|c|}
\hline Category & Expenditure & $\begin{array}{l}\text { Urban } \\
\text { (MYR) }\end{array}$ & $\begin{array}{c}\text { Rural } \\
\text { (MYR) }\end{array}$ \\
\hline \multirow{7}{*}{ Family Head } & Shelter & ${ }^{*} 60.00 / \# 312.00$ & $* 36.00 / \# 234.00$ \\
\hline & Food & 72.00 & 54.00 \\
\hline & Cloth & 36.00 & 18.00 \\
\hline & Medical & 31.50 & 15.50 \\
\hline & Education & - & - \\
\hline & Traveling & 97.50 & 58.50 \\
\hline & Total & ${ }^{*} 297.00 /{ }^{*} 549.00$ & ${ }^{*} 182.00 /{ }^{\#} 380.00$ \\
\hline \multirow{7}{*}{$\begin{array}{l}\text { Adults } \\
\text { (Working) }\end{array}$} & Shelter & - & - \\
\hline & Food & 72.00 & 54.00 \\
\hline & Cloth & 36.00 & 18.00 \\
\hline & Medical & 31.50 & 15.00 \\
\hline & Education & - & - \\
\hline & Traveling & 97.50 & 58.50 \\
\hline & Total & 236.50 & 146.00 \\
\hline \multirow{7}{*}{$\begin{array}{l}\text { Adult (Not } \\
\text { working / not } \\
\text { schooling) }\end{array}$} & Shelter & - & - \\
\hline & Food & 72.00 & 54.00 \\
\hline & Cloth & 36.00 & 18.00 \\
\hline & Medical & 31.50 & 15.50 \\
\hline & Education & - & - \\
\hline & Traveling & - & - \\
\hline & Total & 139.50 & 87.50 \\
\hline \multirow{7}{*}{$\begin{array}{l}\text { Adult } \\
\text { (Schooling) }\end{array}$} & Shelter & - & - \\
\hline & Food & 63.00 & 47.00 \\
\hline & Cloth & 31.50 & 15.70 \\
\hline & Medical & 29.50 & 14.80 \\
\hline & Education & 72.00 & 72.00 \\
\hline & Traveling & 78.00 & 54.00 \\
\hline & Total & 274.00 & 203.50 \\
\hline \multirow{7}{*}{$\begin{array}{l}\text { Teenagers } \\
\text { (Schooling) }\end{array}$} & Shelter & - & - \\
\hline & Food & 63.00 & 47.00 \\
\hline & Cloth & 31.50 & 15.70 \\
\hline & Medical & 29.50 & 14.80 \\
\hline & Education & 54.00 & 54.00 \\
\hline & Traveling & 58.50 & 35.00 \\
\hline & Total & 236.50 & 166.50 \\
\hline \multirow{7}{*}{$\begin{array}{l}\text { Children } \\
\text { (Schooling) }\end{array}$} & Shelter & - & - \\
\hline & Food & 33.70 & 34.00 \\
\hline & Cloth & 22.50 & 11.00 \\
\hline & Medical & 28.80 & 14.50 \\
\hline & Education & 36.00 & 36.00 \\
\hline & Traveling & 58.50 & 35.00 \\
\hline & Total & 179.50 & 130.50 \\
\hline \multirow{4}{*}{$\begin{array}{l}\text { Children } \\
\text { (Not Schooling) }\end{array}$} & Shelter & - & - \\
\hline & Food & 33.70 & 34.00 \\
\hline & Cloth & 22.50 & 11.00 \\
\hline & Medical & 28.80 & 14.50 \\
\hline
\end{tabular}




\begin{tabular}{cccc}
\hline Category & Expenditure & $\begin{array}{c}\text { Urban } \\
\text { (MYR) }\end{array}$ & $\begin{array}{c}\text { Rural } \\
\text { (MYR) }\end{array}$ \\
\hline & Education & 18.00 & 18.00 \\
& Traveling & - & - \\
\cline { 2 - 4 } & Total & $\mathbf{1 0 3 . 0 0}$ & $\mathbf{7 7 . 5 0}$ \\
\hline
\end{tabular}

*Own House \# Rent House

Source: MAIK, 2014

\section{LITERATURE REVIEW}

The purpose of distributing zakat is to alleviate poverty, to protect the welfare, to improve economic hardship and to develop the infrastructure of Muslim society through the distribution of income and wealth from the non-poor to the poor and needy (Yusuf Qardhawi, 2000). Indeed, the effectiveness of zakat distribution has become the main concern of the Muslim society as they hope that the fund could free recipients from poverty or if not to improve their quality of living. As noted, many previous studies had shown the effectiveness of zakat distribution based on the economic perspective of zakat recipients such as the level of income (Mujani, 2005; Ibrahim \& Salleh, 2006; Fuadah, 2004; Mohamad, 2008; Zakariah et al., 2010; Mahyuddin \& Abdullah, 2011). If the income soars, zakat distribution is deemed sufficient. However, if otherwise, the distribution is judged as failing to meet its goal. The income is chosen as an indicator due to the perception that money could solve humans' needs, including poverty. Although it has been well accepted, this assessment receives high criticism. Many claims that this assessment is unfair because human needs are not only confined to money but also include non-monetary items (Fox, L. et al., 2015). In fact, they go beyond the notion of income and encompass social, religion, economic, knowledge, and spiritual, among others (Mohamad Saladin et al., 2011). According to
Rosbi and Sanep (2011), a better assessment of human needs should be evaluated in the perspective of Maqasid al-Sharia that consists of religion, physical-self, knowledge, family and wealth and failure to attain these stipulated needs qualify a human to be poor.

Previous poverty studies in Kelantan demonstrate a considerable number of different results on the needs of the poor and needy in Kelantan. For example, Ahmad Fahme et al. (2018) analyze the food and non-food expenditure among the poor in Kelantan, Malaysia. Findings show that the expenditure pattern on food and non-food items shares among the poor is different. Younger age has a higher expenditure on food while the older age spends higher expenses on non-food items (i.e., housing). The urban area, female and married household head variables show a higher amount of expenditure. The result of this study indicates that not all poor people in Kelantan spend most of their spending on food items. Thus applying the same higher food items on each poor and needy household would overstate the food expenditure and devalues the cost for non-food items. Therefore, it will create a flawed poverty line, which further can create a flawed poverty assessment.

Meanwhile, Senadjki Abdelhak et. al., (2017) found out that education and association memberships are not essential factors that might contribute to the enhancement of poor's livelihood 
while access to irrigation and having savings (at banks and/or homes) were found to have significant negative impact on farmers' monthly income in Kelantan and Terengganu. As a result, assets are found to decrease the income of farmers partially due to the farmers' decision-making strategies, which seems to be poor and inadequate. Therefore, incorporating psychological perspectives such as farmers' behaviors and perceptions are utmost important to understand better the complex mechanisms underlying the farmers who are falling in the poverty trap.

A.N. Ihab et al. (2016) identify the relationship between household food insecurity, food expenditure, and diet diversity among low-income households in rural Kelantan, Malaysia. Based on a cross-sectional survey of low-income households which include non-lactating and non-pregnant mothers and questionnaire method for data gathering, he found out that approximately 83.9 percent of caretaker respondents revealed that they and the members of their households had experienced periods of food insecurity in the 12 months prior to the interview. Of the 83.9 percent, 29.6 percent experienced household food insecurity; 19.3 percent of mothers whose responses to the Radimer/Cornell scale indicated individual food insecurity and 35.0 percent fell into the child hunger category. The findings were consistent with Norhasmah's finding that demographic and socioeconomic characteristics (household size, number of children, number of children attending school, household income, and per capita income) were significantly associated with household food security status in rural and urban areas in Kelantan. Energy intake, fat intake, percentage of energy from fat, and the number of servings of meat, fish, or poultry and legumes were significantly associated with household food security status in rural areas (Norhasmah Sulaiman et al., 2011).

Zakat distribution must acquire at least a level of sufficiency and comfort living for the recipient and his dependents (Yusuf Qardhawi, 2000). The distribution must be in a particular proportion that ensures continuity of quality life where the impact of the distribution is that the recipient must obtain a certain standard of living (Mohd Parid, 2001). Standard of living here means attaining the level of mobilizing essentials (daruriyyat) and comfort (hajiyyat). Syed Othman (2006) clarifies that zakat is the most effective means to assist the poor and needy. He also expresses that the proportion of zakat received by the poor should have helped them improved their standard of living and fulfilling their basic needs (daruriyyat) and wants (hajiyyat) which forms as the minimum of their quality of life. According to Imam Nawawi (1277), (as cited by Ibrahim, E., \& Johnson-Davies, D., 1982), the zakat distribution proportion must take into account the recipient's occupation and living circumstances. In other word, the zakat fund given must differ, and according to the recipients' job and current living expenses that they need (Yusuf Qardhawi, 2000). This is in line with the views of al Ghazali (1111) and al Shatibi (1388) who defines that a good life for every human must cater for two things: essentials (daruriyyat) and comfort (hajiyyat). A similar view is also shared by Afzalurrahman (1991), Mannan (1989), Muslehuddin, (1970). Murrel and Noris (1983) suggest that the quality of life concept is closely 
related to an individual's or the society's feeling of satisfaction towards their living environment that provides enough necessities in the lives.

Concerning this matter, adDusuqi (1815) from the Maliki school of thought and the majority of Islamic scholars from the Hanbali school of thought asserts that the zakat distribution for the poor and needy should be in the form of living support for one month or year (kifayah alSanah $)^{4}$ for the recipient and his dependents. The recipient is entitled to be given zakat until he is freed from poverty. Among the form of aid that could be distributed are necessities, such as food, clothing, and shelter. Gifts in the form of capital for industry such as tools for the craft and others are also encouraged. Al- Shirazi (1640) from the Shafie school of thought, on the other hand, argues that sufficient zakat must be given to the poor and needy as long as they remain poor (kifayah al-Umr ${ }^{5}$ ). Hairunnizam et al. (2004) studied the effect of zakat distribution towards improving the level of life towards zakat recipient (poor and needy) in Malaysia. He found out that 66 percent of the zakat recipient (poor and needy) did not satisfy with their basic level of life mostly of transportation, relationship, and health based on current zakat distribution. However, zakat distribution had brought a positive sign of increasing their quality of life. Muhammad Syukri (2002) found out that 86.3 percent of poor and needy in Bachok district in Kelantan feels that zakat distribution did not reduce their poverty burden and 99.6 percent of them feel that the management of zakat

\footnotetext{
${ }^{4}$ Short term assistance i.e: assistance that can fulfil for one month or one year period

${ }^{5}$ Long term assistance i.e: education fees, business capital assistance
}

nowadays cannot release them from poverty.

Furthermore, Harunnizam Wahid et al. (2004) studied the impacts of zakat on the quality of life of the zakat recipients by examining their satisfaction on the zakat received. It was found that the respondents were generally not satisfied with the zakat distribution as education and social involvement were the only factors that the respondents were satisfied with relative to other quality of life variables such as transportation, communication, health, and shelter. On the other hand, Ahmad et al. (2005) examined the satisfaction levels of zakat payers in Malaysia. Based on the survey conducted, it was established 57 percent of 753 respondents were not satisfied with the current distribution of zakat in Malaysia, which significantly affect their payment of zakat to zakat Institutions. Similar results by Wahid et al., (2010) when he found that almost half of respondents who were not satisfied with zakat institutions in Malaysia choose not to pay zakat. Their dissatisfaction was largely due to inefficiency and lack of transparency in zakat distribution. While Anita Md. Shariff et al. (2011) stated that Malaysia zakat agency needs a wider coverage of zakat agents to facilitate all types of zakat payment over the counter. She also suggests that a Zakat Main Centre should be setup where its functions as a policymaker for zakat distribution, determining zakat proportion for each beneficiary group in each state, consolidating zakat collection, undertaking research and development, supervising zakat institutions to meet short-term needs of beneficiaries and coordinating with the government for long-term development program. At the same time, it is also educating the public about zakat and distributing 
zakat to context and finding solutions to any obstacles that could all beneficiary groups to meet their short-term needs.

\section{DATA AND METHODOLOGY}

This study explores the implications of a different method in estimating the missing items in zakat distribution in Kelantan. To evaluate the missing items in current zakat distribution, this study used in-depth interviews with selected participants from zakat recipients in Kelantan, which was collected between June 2014 and December 2014. The collection of data involved household head from different gender (malefemale) and regions (urban-rural) in Kelantan. The results of the interviews are displayed through narrativedescription in verbatim-transcriptions, as shown below. Sample of the study is 505 households (6.16 percent) of the total population of 8188 poor and needy (fuqara and masakin) households in Kelantan for 2014. Samples selection ranged 56 percent (550) for urban and 44 percent (433) for the rural area for an individual unit. Based on the household unit, the respondent for an urban area consisting of 283 families (56 percent) and 222 families (44 percent) in a rural area. Overall respondent in urban is higher compared to a rural area in both units.

\section{RESULTS}

Results of this study indicate that apart from monthly assistant on food, house, medical, education, transportation, and other personal items, there are four items that most required by poor and needy in current zakat distribution which are 1) assistants during their recessive time such as during illness of the income breadwinner of the family, 2) the needs for additional allowance during pregnancy, infant and lactation period, 3) missing allowance on household head education and 4) the needs for religious saving for hajj and umrah which most of the poor and needy desired

\section{Medical Insurance among Household Head}

The poor have little access to formal health insurance. In many surveys, questions about insurance are not even asked (Ibrahim, P, 2006; Banerjee et al., 2007; Ali. M., 2011 and Johari F. et al., 2013). In Kelantan, most of the expenditures on health are covered by the government's subsidies, own savings, borrowing, or dissaving. Only 2 percent of these expenses were paid by individuals and other self-help groups. Twenty-four percent of the households in the rural area had to borrow to pay for health expenses. The poverty among the poor and needy had brought them to eat less/ unhealthy food or taking their children out of school (Skoufias, 2005). Figure 1 shows the amount of Household head respondent which are covered with insurance and not covered with insurance. 
Figure 1. Respondent Who Have Insurance and Did Not Have Insurance (N=505)

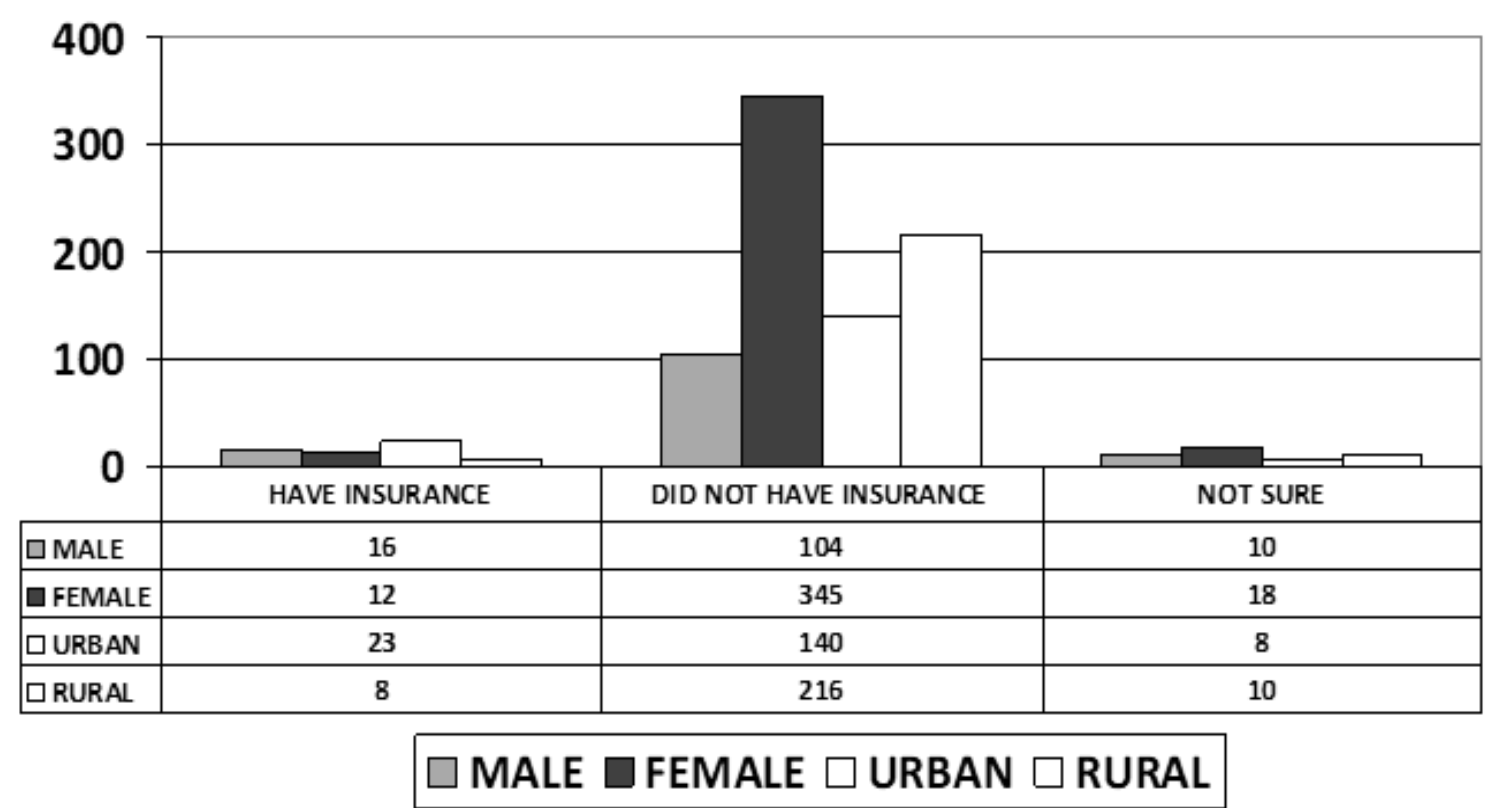

Sources: Research Questions

Results from Figure 1 show that most of the zakat recipients in Kelantan are not covered with insurance. Based on gender variable, the female-headed household is the highest with 345 while the male is 104 . Out of 505 respondent, only 28 respondent who has insurance which is provided by their company while 449 did not have insurance covered and 28 did not make sure that the insurance covers them. In region analysis, the number of respondents who are covered by insurance is higher than that of an urban area with 23 compared to a rural area. However compared between those who covered and not covered, the majority of the respondent did not cover by insurance (356). This low-income of people are vulnerable to many perils as they live in risky environments. However, the poor are more vulnerable to risks than the rest of the population because they are the least able to cope when a crisis occurs. Poverty and vulnerability are related to each other. There is low takeup of poor on income-generating opportunities that might reduce poverty due to their uncertainty about the possibilities of risk might occur (Churchill 2006, Botero et al. 2006).

The need for financial protection among the low income and poor is crucial. There are many unfortunate people who become poorer and struggling with their life to cope with vulnerability (Anthony, E. J., 1987). Most of these people have to sell their assets, borrow money, withdraw children from school, young kids are forced to work to support the family, and hence, the poverty cycle continues from generation to the next generation (Dror, et al., 2007). Figure 2 shows the level of household who can afford to pay for medical expenses among the household head in Kelantan. 
Figure 2. Level of Afford to Pay for Medical Expenses among Household Head (Gender and Regions)

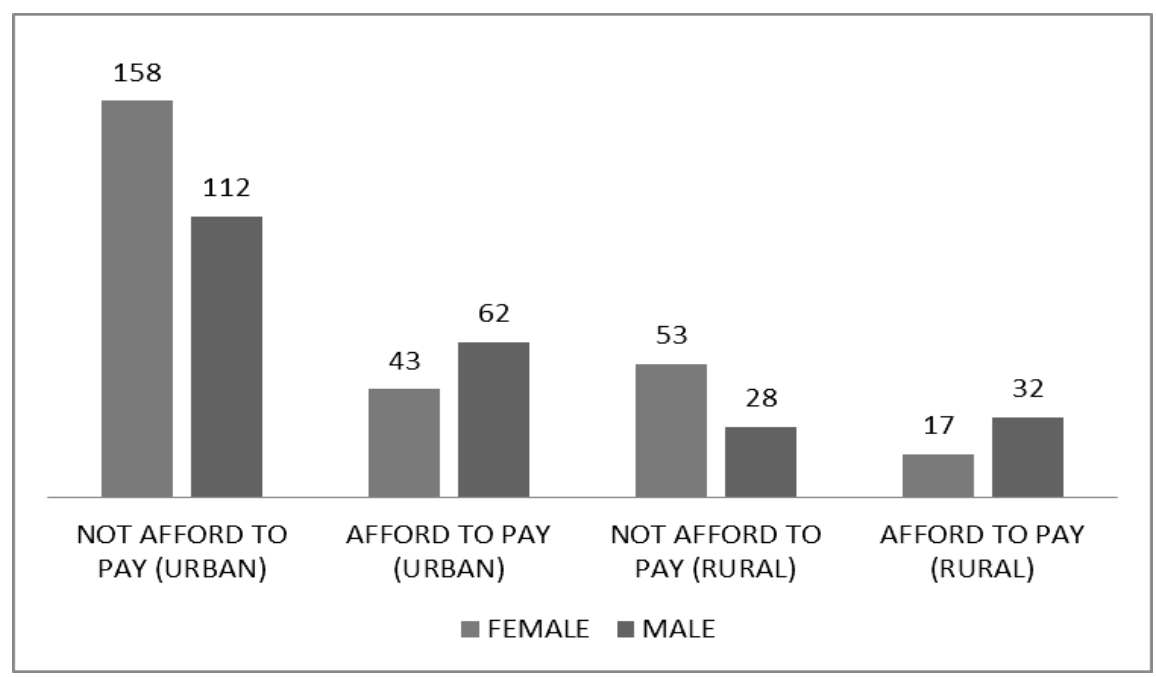

Sources: Research Questions

Results from Figure 2 shows that most of the zakat recipients in Kelantan regardless of gender are not afford to pay for medical insurance in an urban and rural area. The female has a higher amount among those who are not afforded to pay for medical expenses in the urban and rural area. While most of the male-headed are afford to pay for medical expenses in both urban and rural area. This had proved several reasons. First, the payment for medical insurance is perceived as a burden and wasted investment by the poor. Low level of knowledge about the importance of medical insurance is the main factor for them to feel this payment is a burden and wasted investment; second most of the maleheaded household have lower sick persons in their family compared to male-headed household; third, urban area has a greater advantage in getting medical allowance and subsidize compare to rural area which suggests most of the government hospital are located in urban area, and forth, urban residents have a higher chances or probability in becoming sick due to environment, food, water and job description. Among the opinion that was given regarding these issues are:

"It just a waste for me to pay for medical insurance since my income is just sufficient for my family's daily expenses." (Source: Interview conducted on November 17, 2014, at Kota Bharu, Kuala Krai, and Rantau Panjang. Female and Male).

Another opinion:

"Previously, I live with my husband in a rural area. Since he passed away and I require medical attention due to my health condition. I move to town to live with my children. I get so many medical benefits in this area, which most of them 
are not available in a rural area." (Source: Interview conducted on June 12, 2014, at Kota Bharu, Female)

Most urban households have a higher need for risk management options as they are the most vulnerable due to the combined effects of health and weather-related agriculture risks (Matul, 2005). The need for medical insurance is important to reduce the risk of basic healthcare costs, death of the main family breadwinner and to a certain extent, coverage of property loss (Swartz, K., 2005; Jacoby, Hanan G. et.al, 1998; Rose et.al, 1999; Morduch et.al, 1995). Medical insurance cover is crucial for people to insure themselves against the inability to work, set aside money for retirement or protect themselves against the loss of their assets (Gertler et al., 2009). However, less vulnerable people and salaried workers are more willing to buy insurance (Victora, et al., 2003). The same opinion was also acquired during the interview:

"We manage to pay for
insurance. But since my
husband passed away, we
could not afford to pay for
insurance." (Source: Interview
conducted on November 17,
2014, at Kota Bharu, Female)

There also some opinions that says:

"My employer provides me
with insurance during my
working time. But now I had
quit the job to nurture my
disable children, and I did not
have any insurance" (Source:
Interview conducted on
November 17, 21, 24 \& 27,
2014 at Kota Bharu, Pasir Mas,

\author{
Gua Musang and Tumpat, \\ Female)
}

There are many studies which show that capacities to pay might be one of the significant factors reducing demand for insurance (Matul, 2005). Loster and Reinhard (2010) argued that people on low incomes are perfectly willing to pay for a good product if the insurance product can satisfy three conditions: (1) be able to pay the premium, (2) be willing to purchase cover and (3) conclude a contract of insurance. They further stressed that poor people may only afford small premium installments and may not necessarily make a regular contribution.

"I have people with diabetes and always had to go to the hospital. If I afford to pay for insurance, I will pay for it. At least it can cover the medical expenses for my family." (Source: Interview conducted on Jun 10,21 , Oct 5 \& Nov 18 , 2014, at Kota Bahru, Pasir Mas, Pasir Putih, Gua Musang and Kuala Krai, Male \& Female)

According to Cohen and Sebstad (2006), it is very difficult for the poor to get above the poverty line when there is a minor shock. All these implications make life more difficult and stressful. Financial stresses associated with sick or death of a spouse, separation, and divorce create a high degree of vulnerability and financial stress for women (Ali, 2002; McIntyre et al., 2006). Poor households face difficulty in generating regular and substantial income and are extremely vulnerable to economic, political, and physical downturns (Brown \& McCord, 2000). 
"My husband died in 2009 due to an accident at his workplace. This left my children and me with economic shock because I did not work, and my child is still young. Luckily my husband is covered with insurance, which was paid by his employer, and our family received some compensation from the insurance company, which can reduce the burden of our family." (Source: Interview conducted on Jun 10, Oct 10 \& Nov 28, 201, at Kota Bahru, Pasir Mas and Pasir Putih, Female)

One of the major reasons for economic vulnerability is the fact that the death of the head of the family may involve the loss of a major source of income (Fischer, S., 1973). At the death of the husband or father, the economic independence of the family is reduced or, sometimes, lost totally. What can be more pitiable condition than this that the wife and children are looking others more benevolent than the husband and father, in the absence of protection against such dependency on family's breadwinner. The medical insurance is here to assist them and provides adequate amount at the time of sufferings.

Food and Non-Food Insecurity among Pregnant and Nursing Mother

Food and non-food items insecurity among pregnant women is becoming an issue not only developing countries but also in the developed world. The current zakat distribution failed to coop the need for pregnant women, which occurs the food insecurity among them. Food insecurity refers to the inability to afford enough food for an active, healthy life. There is an intimate relationship between food security and poverty (Ahmed, F., \& Siwar, C., 2013). Food insecurity has many health consequences for women in low-income households. Decreased mental health status may put low-income women at risk for household food insecurity because of job instability and associated decreased income, which contribute to food insecurity, or through poor coping skills rendering low-income women unable to acquire enough nutrient-dense foods (Casey P, et al., 2004).

"One of my children is
categorized as special children
(disable). The doctor manages
to detect this problem since my
$2^{\text {nd }}$ semester of pregnancy. The
doctor asks me not to do hard
work, have enough rest, and
take additional medications
and supplements which I
cannot afford to buy. But since
I am the only working person
in my family (widow), I had to
work until the end of my
pregnancy. The hard work and
lack of nutrition affected the
child." (Source: Interview
conducted on May 2, $8,11,24$,
29, July 26, 28, September 1,5 ,
18 2014 at Kota Bahru, Pasir
Mas, Pasir Putih, Gua Musang,
Machang, Tumpat and Kuala
Krai, Female)

There are three main reasons why predictors of food insecurity might be different. First, the nutrient demands of pregnant women differ from those of non-pregnant women, with suggested increased intakes of most vitamins and minerals, and additional nutrition on 
average for a woman of normal weight (Jones SJ, 2007). To achieve optimal gestational weight gain, dietary requirements include nutrient-dense foods that are often more expensive (Olson CM, 2008). At a minimum, purchasing food to increase a woman's daily energy intake means the household faces more constraints in their food budget.

"My family did not afford to buy nutrient food (expensive) and supplement for my pregnancy because we had to spend more on my father in law's medical expenses (suffers kidney problem). I had a miscarriage in my first and second pregnancy." (Source: Interview conducted on May 2, 3, 21, June 14 Oct 4, 2014, at Pasir Mas, Pasir Putih, and Kuala Krai, Female)

Second, a pregnant woman may have more difficulty putting forth the effort to make nutritious food purchases, especially later in pregnancy when she is less mobile (Harnisch, 2012). In response, someone other than the pregnant woman may make food purchases. If this person is less experienced in food shopping, this may lead to less nutritious purchases; if this person is also less experienced in food preparation, more expensive purchases (e.g., fast food) may be made. These two factors together may strain a household's food budget. The same opinion was also acquired during the interview:

"During the last semester of my wife's pregnancy, I had to spend more on food, which increases our family expenses. I had to buy outside food since she is not capable of doing a house job (cook). Since I work until evening, buying outside food is the best options that I have. Now my constrain is to acquire additional income for my baby preparations." (Source: Interview conducted on June 14, July 18 Oct 11, 18, 28, 2014 at Kota Bahru, Pasir Mas, Pasir Putih, Gua Musang, Machang, Tumpat and Kuala Krai, Male)

Third, a woman may exit the workforce during her pregnancy, decreasing the amount of money available for food. A sudden decrease may also present challenges to households that are not used to budgeting on a lower income (Bove $\mathrm{CF}$, 2006; Chaput J-P, 2007). Although food stamps can help a family's financial situation, applying for and receiving food stamps is not an instantaneous process. The nutritional demands and the current psychological state during the major life event of pregnancy pose challenges for all women to eat well. Women from vulnerable households may face additional challenges if they are food insecure. Some opinions that were gathered during the interviews:

"I quit my job during the six months of my pregnancy. I quit my job since I had a miscarriage during my first pregnancy. Now my husband is the only breadwinner for the family. And now I see that he is doing more than one job a day." (Source: Interview conducted on May 3, June 18 Sept 11, 18, Oct 18, 2014, at Gua Musang, Machang, Tumpat, and Kuala Krai, Female). 
Another respondent brings out the same problem:

"I had an accident in 2009, and it affects the condition of my health. I cannot work, and my wife had become the breadwinner for the family. She worked as a gatekeeper for and estate and paid daily (Parttime worker). But now she is pregnant, and I am afraid she might lose her job." (Source: Interview conducted on Sept 11, 2014, at Kuala Krai, Male).

\section{Education Allowances among}

\section{Household Head}

The first guidance given to mankind in the Qur'an was "Iqra" meaning to read, recite or proclaim. Allah S.W.T says in Al-Qur'an which means:

\begin{abstract}
"Read! Recite! Proclaim! in the name of thy Lord and cherisher who created created the human, out of a congealed clot of blood (a leach-like substance). Read, and thy Lord is Most Bountiful. He who taught (the use of) the Pen-taught man that which he knew not.” Al-'Alaq (96: 1-5)
\end{abstract}

In Kelantan, the extremely poor household head spends very little on their education. The expenditure on education generally hovers around 1 percent of household budgets. The fraction does not change very much when we compare the poor to the extremely poor or rural areas to urban areas. Figure 3 shows the differences between the expenditure on household head family's education and total expenditure of family.

Figure 3. Difference between Expenditure on Household Head Family's Education and Total Expenditure of Family (MYR)

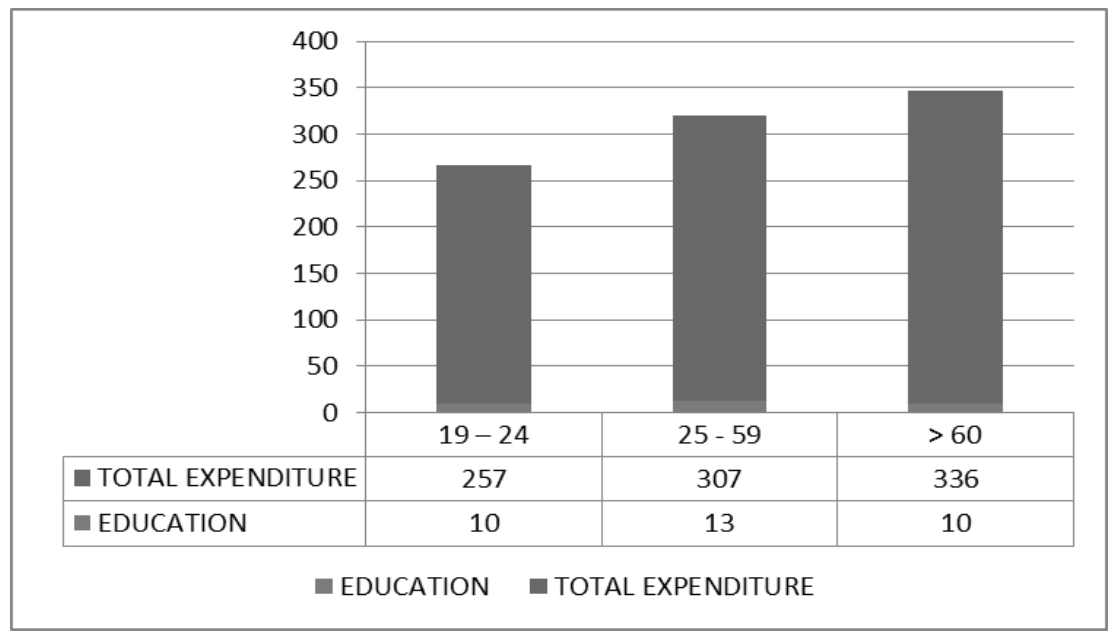

Sources: Research Questions

The result shows that the household head is still spent on education, although the amount is low.
This low level of expenditure on education is not because the household head is not interested in acquiring 
knowledge. In this study sample, at least 80 percent of both Male and female household head aged 19 until 60 and above in extremely poor households are involved in acquiring knowledge. The reason education spending is low is that the household head in low-income families typically attends non-formal education institution or other schools that do not charge a fee. These amounts of expenditure are mostly on buying books (kitab), stationary, minimum fees (commitment fee) and eyeglasses. Although most of these items are not often purchased because of the long period of learning, there are also other items that are regularly purchased and needed in this education process, such as vehicle petrol. Thus, these items of expenditure will acquire an additional amount in family expenses which are not being covered in current zakat distribution.

"I am an old lady. Now the purpose of my life is to worship Allah s.w.t and study Islamic knowledge. That is why I chose to stay at the Pondok (nonformal Islamic Institution). The problem is, I have no income and only get assistant from zakat center. But the assistant is too low and only sufficient to cover for my food and non-food expenses (medical and education expenses)." (Source: Interview conducted on June 13, July 26 Oct 16, 2014, at Kota Bahru, Pasir Putih, Gua Musang, and Kuala Krai, Female).

From an Islamic perspective, there is no fixed age before or after which the parents may or may not teach children the Qur'an or any other aspect of Islamic knowledge. As such, a child may differ from another in his mental ability and intellectual capacity. Some children are seen to mature before others. At times, it is observed that a child is similar to another in age, but the difference in their understandings is huge. Therefore, Islam calls us to learn all kinds of beneficial knowledge.

\section{Religious Saving - Hajj and Umrah}

Islam has five pillars, and one of them is the Hajj, the pilgrimage to Mecca. Every Muslim who is capable physically, mentally and financially is required to perform the Hajj (Khaliq Ahmad et al., 2012). For that purpose, there are Muslims who sell off their assets in their eagerness to perform the obligation. Other Muslims would take a long time to save money to perform the Hajj. On the other extreme are the poor Muslims who are forced to save or borrow to perform the pilgrimage (Ishak, 2011). These situations have negative consequences on the already poor Muslims as indebtedness is further created, and poverty is aggravated. In Kelantan, the poor and needy are still saving a portion of their income for Hajj and Umrah. It shows that poverty is not a barrier for them to perform the Hajj and Umrah. From Figure 4, we can see that the rural has higher saving (39 percent) compare to urban residents (20 percent). While female household head has 13 percent more of saving compare (28 percent) of their income, compared to male household head gender (15 percent). The higher amount of percent among rural and female categories shows that they have less income, which makes a slight amount of saving will have a high percent. 
Figure 4. Total Saving among the Poor and Needy (percent)

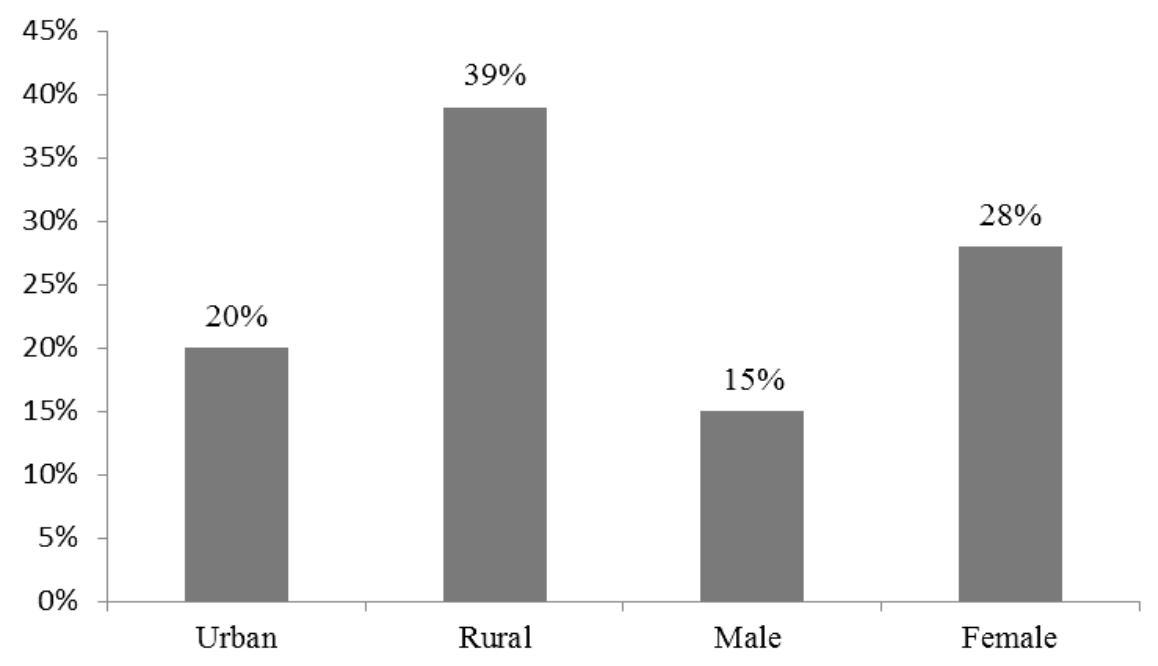

Source: Research Question

Analysis on the number of those who have savings and did not have any saving on Hajj and Umrah in Kelantan shows that the urban (200) and female (122) categories have a higher number of poor and needy with saving. While about 78 percent of the poor and needy in the rural area and 88 percent of male household head gender did not have any savings on Hajj and Umrah. Figure 5 shows the number of several categories with and without savings in Kelantan.

Figure 5. Total Saving among the Poor and Needy (percent)

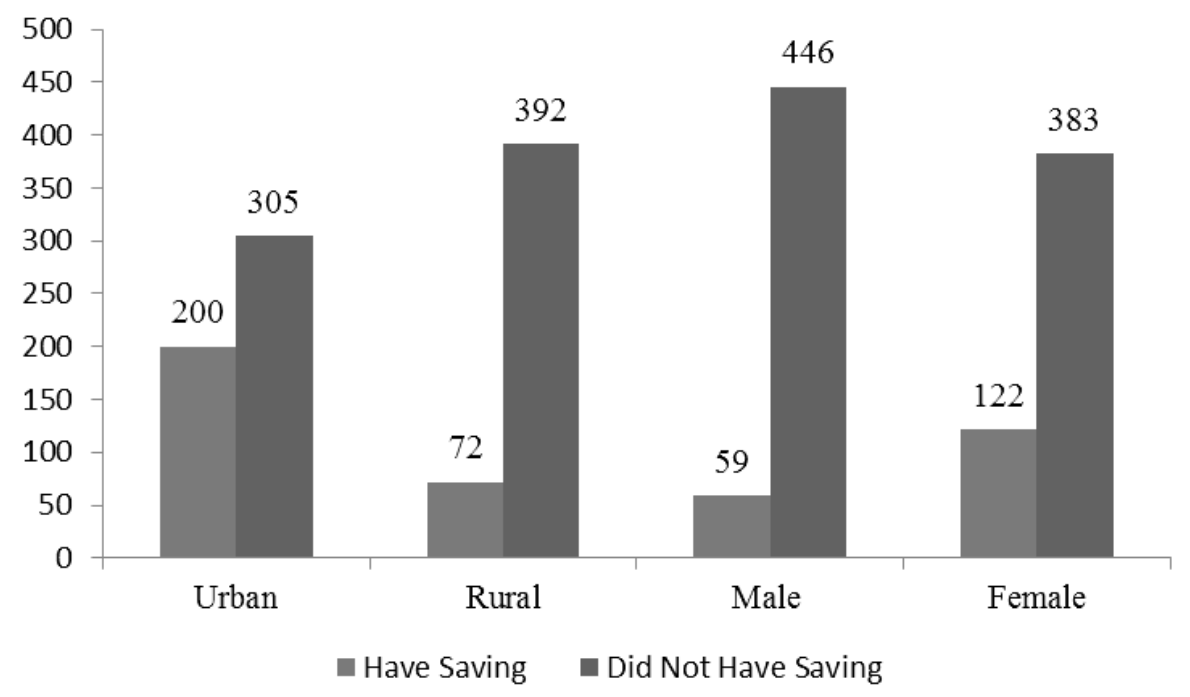

Source: Research Question 
The existing of saving among the income of the poor and needy suggest that they are so determined to perform the fifth pillar of Islam which they manage to adjust a small portion of their low income on savings. Although the performing of Hajj and Umrah is not compulsory for them (poor and needy category), their fortitude on performing their pray in front of Kaabah has made them not seeing their poverty as an obstacle for them. The study by M. N. Zarina (2012) found that out of 133 respondents, one respondent has saved in Tabung Haji, a fund for performing hajj (pilgrimage) in Mecca. This has indicated that low-income households tend to save when it is a default option. Understandably, this option is scarce among these single mothers as they are outside the mainstream employment areas that provide monthly saving schemes such as Employee Provident Fund (EPF) or Social Security Organization (SOCSO) that automatically manage them to save in Tabung Haji (R. Prabhakar, 2007). Being outside wage jobs employment, these single mothers do not have access to many benefits available to government servants and industrial workers like disability benefits, free healthcare, and home/car loans. Many options are not available simply by not having a pay slip to prove their monthly income (M. N. Zarina et al., 2011).

"I had saved in Tabung Haji for about 13 years, but the saving still not sufficient for me to perform the Hajj. It is because I am only saving when I have a surplus in my income. Now I am 65 years old, and I am afraid that I cannot perform the Hajj before I die." (Source: Interview conducted on Oct 16, Nov 22, Dis 16,
2014 at Kuala Krai, Tumpat, Pasir Putih, Bachok and Kota Bharu Female \& Male).

The practices of Hajj require a lot of funds and saving. However, for the poor savings and asset accumulation have been proven to be an important and sustainable means to move the poor out of poverty and improve their economic wellbeing (M. Zhan, 2006). Thus this requires another source of saving fund which the zakat distribution can provide.

"Going to Mecca (perform Hajj) is my dream. But I cannot afford to save for Hajj because of my poverty. My income is only sufficient for my family's daily use. If anything happens, I had to borrow money from my friend and relative. At this time, the main usage of my income is to my family's expenses. But I hope that one day I can perform the Hajj. (Source: Interview conducted on June 13, 15, July 3, 5, 12, 26 Oct 4, 8, 16, 2014 at Kota Bahru, Pasir Putih, Gua Musang, and Kuala Krai, Male \& Female).

The Islamic scholars have a different view as to whether Hajj is included fisabilillah $^{6}$ categories or not. Most of the scholars are of the view that Hajj is not included in the fisabilillah categories on which zakat may be spent. Among them is Ibn Muflih alHanbali (1479) which he states that the Muslims do not benefit from one

\footnotetext{
6 "Alms are for the poor and the needy, and those employed to administer the (funds) for those whose hearts have been (recently) reconciled (to Truth) for those in bondage and in debt in the cause of Allah and for the wayfarer: (thus is it) ordained by Allah, and Allah is full of knowledge and wisdom." [Al-Qur'an 9:60]
} 
individual's Hajj and have no need for it; it is not obligatory in the case of the poor, for whom this duty is waived, and if a poor person still wants to do it, it is better to spend this amount of money on those who are in need or to spend it on helping the Muslims ${ }^{7}$. Imam Ahmad (241) has another view, which is that it is permissible to give zakat to someone who wants to do Hajj. Imam Ahmad quoted as evidence for that the report narrated by Abu Dawood (275) from Umm Ma'qal, who said:

"O Messenger of Allah, I need to go for Hajj and Abu Ma'qal has a young camel." Abu Ma'qal said, "She is telling the truth, and I shall donate it for the sake of Allah."

The Messenger of Allah (pbuh) said:

"Give it to her so that she may go for Hajj on it, for it is for the sake of Allah."

Meanwhile, Ibn Taymiyah (1328) said:

"Whoever has not done the obligatory Hajj and is poor should be given what he needs to do Hajj-i.e., from the zakat funds." 8 Ibn Abbas radiallahu anhuma said, "He (the slave) should be freed from the zakat of his (owners and others) wealth and given from it (Zakat) for Hajj."

Thus, based on the previous argument, we can say that given the zakat for Hajj is still a dispute (Khilaf) subject among the Muslims scholars

\footnotetext{
${ }^{7}$ See al-Mughni, 9/328; al-Majmoo', 6/212.

8 See Taimiyah, I. (1995). al-Ikhtiyarat alFiqhiyah. Beirut: Dar al-Ma 'rifah.
}

(Ulama'). Thus, it is up to the zakat state department to discuss whether it is relevant or not providing the zakat for Hajj.

\section{CONCLUSION}

This study was inspired by information from respondent about their additional needs that is absent in current zakat distribution. It is important that the zakat fund must be disbursed to maximize its benefits towards the recipients spiritually and economically. Lack of access to education aid, medical insurance, food, and non-food Insecurity among Pregnant and Nursing Mother and Religious Saving - Hajj, and Umrah are among the missing items in current zakat distribution. Zakat distribution needs to fulfill the need of its recipients. Islam specifies the eight heads of zakat recipients. It also provides the principles as to how collections should be disbursed. The zakat fund must be disbursed in such a way to maximize the benefits of the recipients spiritually and economically. The zakat recipients must have basic satisfied and to help them participate in economic activities. Zakat expenditure also must be aimed towards achieving economic equity, growth, and stability. Appropriate zakat disbursement must be able to influence the allocation of resources towards achieving the above objective. Hence some missing items in current zakat distribution need to be addressed immediately to make zakat more effective Islamic fiscal instruments.

\section{REFERENCES}

Ab Hamid, S. N., \& Jusoh, W. J. W. (2017). Corporate image of zakat institutions in 
Malaysia. Geografia-Malaysian Journal of Society and Space, 12(2).

Acharya, A., Vellakkal, S., Taylor, F., Masset, E., Satija, A., Burke, M., \& Ebrahim, S. (2012). Impact of national health insurance for the poor and the informal sector in low-and-middle-income countries. EPPI-Centre

Systematic Review. EPPI-Centre, Social Science Research Unit, Institute of Education, University of London.

Afshar, H., (2012). Muslim Women in West Yorkshire Growing up with Real and Imaginary Values amidst Conflicting Views of Self and Society. In The dynamics of race and gender (pp. 135-156). Taylor $\&$ Francis.

Afzal-ur-Rahman.

(1991). Doktrin Ekonomi Islam. Dewan Bahasa dan Pustaka, Kementerian Pendidikan Malaysia.

Anita Md. Shariff, Wan Noor Hazlina Wan Jusoh,Norudin Mansor and Kamaruzaman Jusoff. (2011). A Robust Zakah System: Towards a Progressive Socio-Economic Development in Malaysia. Middle-East Journal of Scientific Research 7 (4): 550-554, 2011

A.N. Ihab, A.J. Rohana, W.M. Wan Manan, W.N. Wan Suriati, M.S. Zalilah and A.M. Rusli. (2016). Food Expenditure and Diet Diversity Score are Predictors of Household Food Insecurity among Low Income Households in Rural District of Kelantan Malaysia. Pakistan Journal of Nutrition 11 (10): 967-973, 2012 ISSN 16805194 (C) Asian Network for Scientific Information, 2012

Ahmed, F., \& Siwar, C. (2013). Food security status, issues and challenges in Malaysia: A

\author{
review. Journal of Food, \\ Agriculture \\ and \\ Environment, 11(2), 219-223.
}

Ahmad Fahme, M.A., Mohd Faisol, I., Muhammad Ridhwan, A.A., \& Fuadah, J.(2014). Konsep Dan Isu Had Kifayah, Kemiskinan Bandar Dan Jantina Dalam Pengagihan Zakat. Labuan E-Journal Of Muamalat And Society, Vol. 8, 2014, Pp. 14-26.

Ahmad Fahme Mohd Ali, Mohd Faisol Ibrahim and Muhammad Ridhwan Ab. Aziz (2018). Food and NonFood Expenditure Trends Among the Poor and Needy in Kelantan, Malaysia. Journal of Entrepreneurship and Business. Vol. 6, Issue 1, pp. 59-78. June 2018. Faculty of Entrepreneurship and Business, Universiti Malaysia Kelantan

Ahmed, H. (2004). Role of zakah and awqaf in poverty alleviation. Jeddah: Islamic Development Bank, Islamic Research and Training Institute.

Ahmad, S., \& Wahid, H. (2005). Persepsi agihan zakat dan kesannya terhadap pembayaran zakat melalui institusi formal.Jurnal Ekonomi Malaysia, 39(17), 53.

Ali, M., \& Fahme, A. (2011). Role of Zakat in Poverty Reduction in Kelantan, Malaysia (Master Science dissertation, Universiti Putra Malaysia).

Al-Ghazali,Abu Hamid Muhammad Ibn Muhammad. (1997). Al-Mustafa Min 'Ilm al-Usul, Beirut : Dar Ihya' al-Turath al-Arabi.

Al Dusuqi. n.d. Hasyiah. Kaherah: al Halabiah.

Al Syirazi, n.d. al Muhazzab. Kaherah: Al Halabiah.

Abu Ishak al-Syatibi, (1997). AlMuwa faqat Fi Usul al-Syariah, 
Beirut : Dar al-Makrifah, Vol. 3, jld.2, pp.326.

Bakar, M. H. A., \& Abdghani, A. H. (2011). Towards achieving the quality of life in the management of zakat distribution to the rightful recipients (the poor and needy). International Journal of Business and Social Science, 2(4).

Bakar, N. B. A., \& Rashid, H. M. A. (2010). Motivations of paying zakat on income: Evidence from Malaysia. International Journal of Economics and Finance, 2(3), $76 .$.

Banerjee, A. V., \& Duflo, E. (2007). The economic lives of the poor. Journal of economic perspectives, 21(1), 141-168.

Beverly, S., Sherraden, M., Cramer, R., Williams Shanks, T., Nam, Y., \& Zhan, M. (2008). Determinants of asset holdings.Asset building and low-income families, 89-151.

Berner, E., Gomez, G., \& Knorringa, P. (2012). 'Helping a large number of people become a little less poor': The logic of survival entrepreneurs. The European Journal of Development Research, 24(3), 382-396.

Bove, C. F., \& Olson, C. M. (2006). Obesity in low-income rural women: qualitative insights about physical activity and eating patterns. Women \& Health, 44(1), 57-78.

Brown, A. F., Gregg, E. W., Stevens, M. R., Karter, A. J., Weinberger, M., Safford, M. M., ... \& Beckles, G. L. (2005). Race, ethnicity, socioeconomic position, and quality of care for adults with diabetes enrolled in managed care: the Translating Research Into Action for Diabetes (TRIAD)
study.Diabetes $\quad$ care, 28(12), 2864-2870.

Brown, W. (2001). Microinsurance-the risks, perils and opportunities. Small Enterprise Development, 12(1), 11-24.

Casey, P., Goolsby, S., Berkowitz, C., Frank, D., Cook, J., Cutts, D., ... \& Meyers, A. (2004). Maternal depression, changing public assistance, food security, and child health status. Pediatrics, 113(2), 298304.

Chaput, J. P., Gilbert, J. A., \& Tremblay, A. (2007). Relationship between food insecurity and body composition in Ugandans living in urban Kampala. Journal of the American

Dietetic Association, 107(11), 1978-1982.

Charsley, K. (2005). Unhappy husbands: Masculinity and migration in transnational Pakistani marriages. Journal of the Royal Anthropological Institute, 11(1), 85-105.

Churchill, C. (2006). Protecting the poor: A microinsurance compendium, Munich $\mathrm{Re}$ Foundation. ILO, Geneva.

Churchill, C., \& Guérin, I. (2004). Microfinance-led strategies to eliminate bonded labour. ILO Working Paper, www. ilo. org/public/english/employment/fin anceldownload/churchguer. pdf.

Cohen, M., \& Sebstad, J. (2006). The demand for microinsurance. Protecting the poor: A microinsurance compendium, 25-44.

Das, N., Yasmin, R., Ara, J., Kamruzzaman, M., Davis, P., Behrman, J., ... \& Quisumbing, A. (2013). How do intrahousehold 
dynamics change when assets are transferred to women? Evidence from BRAC's Challenging the Frontiers of Poverty ReductionTargeting the Ultra Poor program in Bangladesh. (December 1, 2013). IFPRI Discussion Paper 01317. Available at SSRN:https://ssrn.com/abstract=2 405712 or http://dx.doi.org/10.2139/ssrn.240 5712

Dolphin, T. (2009). Saving and assetbuilding in low-income households. Institute for Public Policy Research.

Dror, D. M., Radermacher, R., \& Koren, R. (2007). Willingness to pay for health insurance among rural and poor persons: Field evidence from seven micro health insurance units in India. Health policy, 82(1), 12-27.

Dror, I. (2010). Voluntary Affiliation to Micro Health Insurance and Social Capital Among ResourcePoor Persons: Initial Evidence from India. In Microinsurance: an Innovative Tool for Disaster and Risk Reduction, Global Risk Forum GRF, Davos. Available at SSRN:https://ssrn.com/abstract=2 $\underline{057755}$

Fafchamps, M. (2003). Rural poverty, risk and development. Edward Elgar Publishing.

Fox, L., Wimer, C., Garfinkel, I., Kaushal, N., \& Waldfogel, J. (2015). Waging war on poverty: Poverty trends using a historical supplemental poverty measure. Journal of Policy Analysis and Management, 34(3), 567-592.

Fuadah, J. (2004). Keberkesanan zakat dalam mengatasi masalah kemiskinan di Negeri Melaka. Unpublished Master Dissertation.
Universiti Malaya, Kuala Lumpur, Malaysia.

Gertler, P., Levine, D. I., \& Moretti, E. (2009). Do microfinance programs help families insure consumption against illness?.Health economics, 18(3), 257-273.

Wahid, H., Ahmad, S., \& Kader, R. A. (2009). Pengagihan zakat oleh institusi zakat di Malaysia: Mengapa masyarakat Islam tidak berpuas hati?. Jurnal Syariah, 17(1), 89-112.

Hairunnizam Wahid, Sanep Ahmad \& Mohd Ali Mohd Nor, (2004), The effects of zakat on quality of life to the needy and poor, The Journal of Muamalat and Islamic Finance Research, 1 (1), pp.151166 [in Bahasa Malaysia].

Hamilton, W.L., Cook, T.J., Thompson, W.W., Buron, L.F., Frongillo, E.A., Olson, C.M. and Wehler, C.A. (1997). Household Food Security in the United States in 1995. US Department of Agriculture Food and Consumer Service, Washington D.C., USA, pp. 1- 69.

Hassan, M. K. (2010, January). An integrated poverty alleviation model combining zakat, awqaf and micro-finance. In Seventh International Conference-The Tawhidic Epistemology: Zakat and Waqf Economy, Bangi, Malaysia (pp. 261-281).

Hegewisch, A., \& Gornick, J. C. (2011). The impact of work-family policies on women's employment: a review of research from OECD countries. Community, Work \& Family, 14(2), 119-138.

Hubbard, J., \& Singh, P. (2009). The evolution of employee benefits at the economical insurance 
group. Compensation \& Benefits Review, 41(6), 27-35.

Ibrahim, F. and Salleh, M.F.M. (2006), "Stochastic frontier estimation: an application to local government in Malaysia", Malaysian Journal of Economic Studies, Vol. 43 Nos 1/2, pp. 85-95.

Ibrahim, P. (2006). Economic role of Zakat in reducing income inequality and poverty in Selangor (Doctoral dissertation, Universiti Putra Malaysia).

Ibrahim, E., \& Johnson-Davies, D. (1982). An-Nawawi's Forty Hadith. Kazi Publications.

Ishak, M. S. B. H. (2011). Tabung Haji as an Islamic Financial Institution for Sustainable Economic Development. International Proceedings of Economics Development \& Research, 17.

Jacoby, H. G., \& Skoufias, E. (1998). Testing theories of consumption behavior using information on aggregate shocks: Income seasonality and rainfall in rural India. American Journal of Agricultural Economics, 80(1), 114.

Department of Zakat, Hajj and Waqf (JAWHAR). (2007). Zakat Management Manual. Putrajaya: Jabatan Perdana Menteri.

Johari, F., Ali, A. F. M., \& Ab Aziz, M. R. (2015). The Role Of Zakat Distribution Among Muallaf (New Convert) In Reducing Poverty In Selangor, Malaysia. İktisat Politikas1 Araştırmaları Dergisi,2(1), pp.3956.

Johari, F., Aziz, M. R. A., Ibrahim, M. F., \& Ali, A. F. M. (2013). Zakat Distribution and Programme for
Sustaining Muallaf Belief and Thought. Jurnal Teknologi, 66(1). Jones, S. J., \& Frongillo, E. A. (2007). Food insecurity and subsequent weight gain in women. Public health nutrition, 10(02), 145-151.

Kahf, M. (2004). Islamic banks: the rise of a new power alliance of wealth and Shari'a scholarship. The politics of Islamic finance, 17-36.

Katungi, E., Edmeades, S., \& Smale, M. (2008). Gender, social capital and information exchange in rural Uganda.Journal of International Development: The Journal of the Development Studies Association, 20(1), 35-52.

Kessler, R. C., Barber, C., Birnbaum, H. G., Frank, R. G., Greenberg, P. E., Rose, R. M., .. \& W Wang, P. (1999). Depression in the workplace: effects on short-term disability.Health affairs, 18(5), 163-171.

Latif, M. D. A. (2001). Pendekatan kepada cara pengagihan dana zakat yang dinamik dan sesuai dengan suasana semasa. [Current and dynamic approaches in the methods of zakat distribution] In Nik Mustapha (Eds.), Kaedah pengagihan dana zakat [Methods of zakat distribution] (pp. 3964). Kuala Lumpur: IKIM.

Mahyuddin Abu Bakar \& Abdullah Abd Ghani. (2011).Towards Achieving the Quality of Life in the Management of Zakat Distribution to the Rightful Recipients(The Poor and Needy).International Journal of Business and Social Science.2(4):237-245.

Manning, W. G., Newhouse, J. P., Duan, N., Keeler, E. B., \& Leibowitz, A. (1987). Health 
insurance and the demand for medical care: evidence from a randomized experiment. The American economic review, 251277.

Mannan, M. A. (1989). Effect of Zakah Assessment and Collection on the Distribution of Income in Contemporary Muslim Countries. Management of Zakah in Modern Muslim Society. Jeddah: IDB.

Majlis Agama Islam Kelantan (MAIK) Report (2013), Majlis Agama Islam dan Adat Istiadat Negeri Kelantan.

Matul, M. (2005). Demand for micro insurance in Georgia: quantitative study results. In 8th Annual Conference on Microfinance Institution, Bucharest.

McDermott, R., Goldman, S., \& Varenne, H. (1984). When school goes home: Some problems in the organization of homework. The Teachers College Record, 85(3), 391-409.

McIntyre, D., Thiede, M., Dahlgren, G., \& Whitehead, M. (2006). What are the economic consequences for households of illness and of paying for health care in low-and middle-income country contexts?. Social science \& medicine, 62(4), 858-865.

Merican, I., \& bin Yon, R. (2002). Health care reform and changes: the Malaysian experience. Asia Pacific Journal of Public Health, 14(1), 17-22.

Mohamad, A. (2008). Perception of academicians towards zakat administration particularly zakat distribution: The case of Selangor and Kelantan. Unpublished Master Thesis, International Islamic University Malaysia, Kuala Lumpur.
Mohamed Saladin Abdul Rasool, Mohd Fauzi Mohd Harun, Ariffin Mohd Salleh, Nor Aini Haji Idris. (2011). Poverty Measurement in Malaysian Zakat Institutions: A Theoretical Survey. Jurnal Ekonomi Malaysia 45(2011) pp. $123-129$

Mohd. Saleh Bin Awang. (1986). Haji di-Semenanjung Malaysia: Sejarah dan Perkembangannya Sejak Tahun 1896-1985 (Hajj in Peninsula Malaysia: History and Development Since 1896-1985). Kuala Trengganu: Syarikat Percetakan Yayasan Islam Terengganu Sdn. Bhd., Kuala Terengganu

Mohd Parid Syeikh Ahmad. (2001). Kaedah Pengagihan Dana Zakat: Satu Perspektif Islam. Dalam Nik Mustapha Nik Hassan (pent). Kaedah Pengagihan Dana Zakat; Satu Perspektif Islam. Kuala Lumpur: IKIM.

Senadjki Abdelhak, Jamalludin Sulaiman \& Saidatulakmal Mohd. (2017). The Role of Assets in the Enhancement of Households' Income: A Study of Poverty Alleviation among Rural Communities of Kelantan and Terengganu. Asian Social Science; Vol. 8, No. 11; 2012. Canadian Center of Science and Education

Salleh, M. S. (2002). Lokalisasi Zakat: Satu Cadangan Teoritis. Zakat Specialist Meet, 21-22.

Salleh, M. S. (2006). Lokalisasi Pengagihan Zakat: satu Cadangan Teoritis. dalam Hailani \& Abdul Ghafar (penyt).Zakat: Pensyariatan, Perekonomian \& Perundangan. Bangi: Penerbit Universiti Kebangsaan Malaysia.

Mujani Tarimin. (2005). Zakat Menuju Pengurusan Profesional. Kuala 
Lumpur : Utusan Publication and Distribution.

Munshi, K., \& Rosenzweig, M. (2009). Why is mobility in India so low? Social insurance, inequality. and growth. Working papers, Brown University, Department of Economics.

Muslehuddin, M. (1970). Commenwealth of Islamic Countries and the Muslim World Bank. The Criterion.

Murrell, S. A., \& Norris, F. H. (1983). Quality of life as the criterion for need assessment and community psychology.Journal of Community Psychology, 11(2), 88-97.

Norhasmah Sulaiman, Zalilah Mohd Shariff, Rohana Abdul Jalil, Mohd Nasir Mohd Taib, Mirnalini Kandiah, and Asnarulkhadi Abu Samah. (2011). Validation of the Malaysian Coping Strategy Instrument to measure household food insecurity in Kelantan, Malaysia. Food and Nutrition Bulletin, vol. 32, no. 4 (C) 2011, The United Nations University

Patel, S. (2002). Insurance and Poverty Alleviation:'The Cooperative Advantage'. ICMIF.

Payne, T. H., Bates, D. W., Berner, E. S., Bernstam, E. V., Covvey, H. D., Frisse, M. E., ... \& Lehmann, H. P. (2012). Healthcare information technology and economics. Journal of the American Medical Informatics Association, 20(2), 212-217.

Prabhakar, R. (2007). Attitudes towards the Child Trust Fund: What do parents think? The British Journal of Politics and International Relations, 9(4), 713729.
Rasool, M. S. A., Salleh, A. M., \& Harun, M. F. M. (2012). Poverty measurement by Islamic institutions. International Journal of Social Management, Economics and Business Engineering, 6(5).

Mohd, Noor and Abdul Rahman, Zuriah. (2012) Financial Protection for the Poor in Malaysia: Role of Zakah and Micro-takaful. Journal of King Abdulaziz University: Islamic Economics, Vol. 25, No. 1, 2012. Available at SSRN: https://ssrn.com/abstract=3 067879

Rosbi, A. R., \& Sanep, A. (2011, November). Kesan kerohanian program bantuan modal asnaf oleh Lembaga Zakat Selangor (LZS). In Proceedings The World Universities 1st Conference (pp. 22-24).

Sadeq, A. M. (2002). Waqf, perpetual charity and poverty alleviation. International Journal of Social Economics, 29(1/2), 135-151.

Salman, K., \& Zoucha, R. (2010). Considering faith within culture when caring for the terminally ill muslim patient and family. Journal of Hospice \& Palliative Nursing, 12(3), 156163.

Samad, S. A., \& Mansor, N. (2017). Population ageing and social protection in Malaysia. Malaysian Journal of Economic Studies, 50(2), 139-156.

Ahmad, S., Wahid, H., \& Mohamad, A. (2006). Penswastaan institusi zakat dan kesannya terhadap pembayaran secara formal di Malaysia. International Journal of 
Management

Studies

(IJMS), 13(2), 175-196.

Shariff, Z. M., \& Lin, K. G. (2004). Indicators and nutritional outcomes of household food insecurity among a sample of rural Malaysian women. $J$ Nutr, 30, 50-55.

Skoufias, E., \& Quisumbing, A. R. (2005). Consumption insurance and vulnerability to poverty: A synthesis of the evidence from Bangladesh, Ethiopia, Mali, Mexico and Russia. The European journal of development research, 17(1), 24-58.

Sokol, M. C., McGuigan, K. A., Verbrugge, R. R., \& Epstein, R. S. (2005). Impact of medication adherence on hospitalization risk and healthcare cost. Medical care, 521-530.

Townsend, M. S., Aaron, G. J., Monsivais, P., Keim, N. L., \& Drewnowski, A. (2009). Lessenergy-dense diets of low-income women in California are associated with higher energyadjusted diet costs-. The American journal of clinical nutrition,89(4), 1220-1226.

Victora, C. G., Wagstaff, A., Schellenberg, J. A., Gwatkin, D., Claeson, M., \& Habicht, J. P. (2003). Applying an equity lens to child health and mortality: more of the same is not enough.The Lancet, 362(9379), 233-241.

Wahid, H., Ahmad, S., \& Kader, R. A. (2010). Pengagihan Zakat oleh Institusi Zakat kepada Lapan Asnaf: Kajian di Malaysia. Jurnal Pengurusan JAWHAR,4(1), 2010.

Wahid, H. and R.A. Kader, 2010. Localization of Malaysian zakat distribution: Perceptions of amil and zakat recipients: Proceedings from Seventh International

Conference- the tawhid epistemology: zakat and wakaf economy, Bangi, Malaysia, pp: 461-484

Yusuf Qardhawi (2000). Fiqh al-Zakah, English Translation by Monzer Kahf, Jeddah, Scientific Publishing Centre, King Abdulaziz University

Zakariah, A.R., Amini A.A. \& Ahmad Fahme, M.A. (2010). Peranan agihan zakat dalam mengurangkan jurang kemiskinan: Satu kajian di Kelantan. Proceedings The ISDEV International Islamic Development Management Conference (IDMAC 2010). Zakat Transformation: From Subsistence to productive, 21-22 December. Universiti Sains Malaysia.

Zarina, M. N., \& Kamil, A. A. (2012). Sustaining the Livelihood of Single Mothers through Wealth Creation and Savings Opportunities: A Long Road Ahead. International Journal of Trade, Economics and Finance, 3(2), 126.

Zhan, M. (2006). Assets, parental expectations and involvement, and children's educational performance. Children and Youth Services Review, 28(8), 961-975. 